\title{
Raising Engagement and Enhancing Learning: School Community Partnerships That Work for Students at Promise
}

\author{
David Zyngier \\ Faculty of Education, Monash University, Melbourne, Australia. \\ Email: david.zyngier@monash.edu \\ Received August 22 ${ }^{\text {nd }}, 2011$; revised September 27 $7^{\text {th }}, 2011$; accepted October $9^{\text {th }}, 2011$.
}

\begin{abstract}
This paper reports on a pilot study that investigates the widely reported issue of underachievement of students from Culturally Linguistically and Economically Diverse (CLED) backgrounds. It involves 15 university education faculty student volunteers and over 40 students and their families in primary (elementary) schools situated in disadvantaged communities of Victoria whose students come from 40 different nationalities, speaking 36 languages and with 75 per cent of its student cohort coming from Non English Speaking Backgrounds. A partnership was formed to focus on the problem of CLED children's disengagement from their academic learning. We focus on how a productive partnership between schools and a university impact on inclusive teaching and learning practices both at the school and the university level. We investigate whether such an intervention can have an impact on engagement levels and the learning and social outcomes of students from refugee, migrant and working class families. Privileging participant voice we analyze data from interviews, surveys and focus groups with students, teachers and parents to argue that such a program has the capacity to re-engage underachieving students at a minimal cost to the community as an alternative model to other expensive and unsuccessful intervention programs. We conclude that at the core of this successful program is the need for both participants to feel they are empowered in the process. We know that student outcomes can be enhanced when the students feel connected to and involved in their community. Through this project, the students have the opportunity to experience greater community engagement leading to improved school attendance and retention, as well as better academic outcomes.
\end{abstract}

Keywords: Community Partnerships, Culturally Linguistically and Economically Diverse Students, Student Engagement

\section{Introduction}

We live in a society where despite widespread concerns about children and teenagers, the vast majority of adults are not actively involved in the lives of young people outside of their own families. This reality has a profound impact on community life and on young people's development. Without the attention of many adults in all parts of their lives and community, young people are deprived of important sources of guidance, nurture, care, and socialization. (Scales, Benson, \& Mannes, 2002)

This paper analyzes a specific community engagement program, the Enhanced Learning Improvement in Networked Communities (E-LINCs), an innovative project that partners university and community volunteers with schools where student learning difficulties and disengagement are significant issues. The focus of this research is school-community engagement, as productive and authentic work with cultural, linguistic and economically diverse (CLED) communities in order to redress social disadvantage. Theories of community strengths underpin support to teachers "meeting and partnering with community members and agencies, to learn about the important community strengths that can be utilized in a more culturally relevant education" (Noel, 2010: p. 10).

We ask whether such an intervention can have an impact on engagement levels and the learning and social outcomes of students "at-promise" from refugee, migrant and working class families.

Privileging participant voice we analyze data from interviews,

"Swardener (1995) uses the positive term children "at-promise" rather than negative children "at-risk". surveys and focus groups with students, teachers and parents to argue that such a program has the capacity to re-engage underachieving students at a minimal cost to the community as an alternative model to other expensive and unsuccessful intervention programs. This multi level approach required buy in from teachers, researchers, the community and other young people to make it a success.

We conclude that at the core of this successful program is the need for all participants to feel they are empowered. We know that student outcomes can be enhanced when the students feel connected to and involved in their community. Through this project, the students have the opportunity to experience greater community engagement leading to improved school attendance and retention, as well as better academic outcomes. The research was awarded a competitive national award for its significant contribution to Australian education.

\section{Engaging Pedagogies and Achievement}

The problem of Cultural, Linguistic and Economically Diverse (CLED) children's disengagement from academic learning (Naidoo, 2008) is evident in the primary schools involved in the project. In contrast with individualist models, a critical transformative understanding (Zyngier, 2010) considers "whether engagement is a key centralising factor in the successful implementation of empowering classroom pedagogies” (McFadden \& Munns, 2002: p. 359). This approach delivers improved outcomes for young people by challenging "the school context in which the young people are located” (Stewart, 1998: p. 4). A transformative approach involves pedagogical reciprocity where 
teachers and students learn together and from each other (Zyngier, 2010).

\section{School-Community Partnerships Enhance Social Capital}

Case \& Hadfield (2006: p. 3) warn against a view of education that considers the work of schools in isolation from their communities and note a cultural shift away from "previously isolated and entrenched modes of working" towards "more inclusive and holistic" multi-agency partnerships in education.

Schools are increasingly looking to communities to help build capacity and improve educational outcomes (Berg, Melaville, \& Blank, 2006). Holloway (2004) argues that "efforts to improve student performance must focus on the community as a whole including the university as a community organisation, not just on the school” (p. 89). Howard (2006) similarly suggests that while there is no single strategy powerful enough to close academic achievement gaps, social capital (or networks) "should be an element of a more inclusive and comprehensive effort" to narrow and eliminate these gaps (p. 12).

Melaville, Berg \& Blank (2006) note the importance of young people having access to social capital and network of social supports connecting them to shared values, information, guidance, and contacts. "Each individual needs to belong to a 'community of practice' where beliefs are shared, skills are learned, and collective resources and interactions hold them together” (Melaville, Berg, \& Blank, 2006: p. 20).

Strong school-community partnership is associated with better school attendance, quality school programs, improved student behavior, and discipline (Michael, Dittus, \& Epstein, 2007) while partnerships between schools and other organizations play an important role in addressing some of the non-academic barriers to learning, such as poor peer relations, family conflict and instability, negative community norms and disorganization (Anderson-Butcher, Stetler, \& Midle, 2006).

What makes this project so effective is that it bonds, bridges and links schools with their communities of practice which includes the university (Moll, Amanti, Neff, \& Gonzalez, 1992). Social capital "has a major impact on student achievement and health” (Howard, 2006: p. 9), results in better school performance (Leana \& Pil, 2006; Plagens, 2003; Putnam, 1999), and enhances the productive capacity of both individuals and groups (Croninger \& Lee, 2001). Social capital can promote educational achievement because community social capital influences students' educational performance through the variety of programs, organizations and activities available in the community. "Whenever there is a collective commitment by families, schools and communities to work in partnership... young people stay and succeed in school” (Israel \& Beaulieu, 2004a: p. 50).

\section{The Enhanced Learning Program}

CLED students' literacy development is often lower than the expected age level, which means that functioning successfully in the classroom and obtaining skills and knowledge may be difficult. The major goal of the program was to establish an effective, ongoing and well-attended after-school program for any students who were underachieving and/or disengaged, and who volunteered to attend in order to improve their learning. Our focus was on the problem of children's disengagement from their academic learning. The principal was clear about who was to be involved and why:

The idea is for those students who are perhaps not doing as well as they could, it could be bright kids who are in the program as well ... It's not for under performance or the kids who are low achievers, it's for kids who perhaps could have the bar raised for them. It's an opportunity to do that. I call it vicarious learning basically, because school for a lot of these kids is a bit of a pain [but] we don't want to replicate school again, so they're doing more school stuff.

The programs ran for 8 weeks with sessions from 3:30 pm to 5:30 pm twice weekly. The afternoon started with volunteers playing some vigorous outside games with the children to 'shake out the sillies' before sitting down to a communal afternoon tea to 're-charge their batteries'. Children then had the option to either complete set homework or work towards their chosen learning goals. The majority, in choosing the latter, were excused from homework completion, opting for learning goals as diverse as story writing, project work, spelling, handwriting, numeracy activities like times-tables or computer skills. The volunteers assisted with these choices, which the children's parents would not have been able to help with at their homes.

After one hour of games, food and individual work on learning goals or homework, the groups participated in enhanced learning that included student choice opportunities in educationally rich activities. The volunteers developed the following twice-weekly Enhanced Learning Workshops:

- Animation \& movie-making

- Music, Dance \& Drama

- Everyday Science

- Everyday Cooking

- Digital Photography

- Art \& Mural Development

\section{Findings}

We documented through photography, video and audio recording the diverse projects developed by volunteers at two schools. We also conducted four focus groups with school pupils and surveyed and interviewed volunteers.

E-LINCs built meaningful relationships for young people with their peers and other community members and provided a space where young people learned new skills from community members sharing their expertise. The program was not designed for any particular student type-a principal adds that:

Our aim is I think to have as many children who want to be involved, as well as those who need to be involved because there's no reason why children who aren't already doing well, can't even do better.

\section{Enhanced Engagement}

As many of the volunteers were from white, middle class backgrounds they commented positively about working with CLED children for the first time:

Getting to know and understand students from different backgrounds to myself. It's been fantastic being involved with a school where there is so much diversity; it's been a great experience in that respect.

The volunteers were also clear about their involvement:

I thought that this project truly benefited disengaged children and I wanted to be a part of that ... I would like to try to help the students that have difficulty in engaging with their classroom school work. ... I wanted to work more with students who find it difficult to engage in school work, by working with 
them to make the learning fun and enjoyable, that is of interest to them.

The volunteers understood that student disengagement was a real issue for them to tackle and commented about their experiences with the children as they observed the changes in engagement:

The students loved the program; they all had a favorite part they liked to talk about. I liked that we built a good strong report with them so that they felt they could tell us if they thought the program needed changing or how to improve it. ... For the majority of the students by midway they were really engaged and were loving the activities and even doing the homework (and they liked getting help).

Seeing the students grow to trust us and enjoy the program, in particular seeing them apply themselves was really rewarding. One student who had been quite difficult previously, really applied herself over the last few sessions and even opened up to me a little.

The students commented about the program that:

It's really fun. Yeah we had a photo hunt. And we made post cards. We made our own videos. It's funny, it's fun, yeah.

I'm happy because I get lots of fun work. I don't like boring work

I learnt my division.

Now I know how to make harder experiments and they're actually easy

It helped me for class and for life as well.

It is was really fun and it makes me get more active instead of sitting at home and watching TV ... or turn the computer.

Many of the students involved spend the time between school and when their parents arrive home with no purposeful play or directed activity. Many students were now attending school regularly.

The volunteer reflected that:

According to the teachers she was known as the 'sick bay girl', she would basically live in the sick bay and would not want to participate in class what so ever. I noticed that after a few sessions with Enhanced learning, she was becoming more involved in the Science activities and always had a smile on her face. One day, the girl's teacher approached me and said that she taught her whole class one of the Science sessions I had taught her and she has become more involved in class.

\section{Enhanced Learning Outcomes}

Students were able to distinguish clearly between the kinds of class work they usually experience in class and the Enhanced Learning program:

The science we do isn't really work, it's just experimenting, like we make slime, we make tornadoes in bottles and stuff like that. That's why I love Enhanced Learning. Enhanced Learning is fun.

Volunteers reflected on the program and its positive effect on the students:

Seeing them work hard on their learning goals because they want to understand what is in front of them and asking you if they have the right answer after you've just helped them and when you say "yes" watching them smile and keep going with their work.

This is confirmed by one student who was confident that she could now even:

Tell my teacher how to make like tornadoes in bottles and, slime, and how to make the lava lamp.

A number of the volunteers reported on positive change in the students:

Seeing themselves improve in their performance skills and actually being given time and help with doing their homework which they told us they do not get at home.

The students are glad to have us there to help them with their homework and ask lots of questions and I believe have become more confident in completing their work.

We had no trouble getting them to do their work as we provided a place for them to have fun and be themselves, they weren't in any competition with each other, as they were all different.

The students had changed from shy underachievers able to identify what they had gained from Enhanced Learning as one commented:

It helps me, like it helps me to learn science and stuff like that, like they help us with our homework. It's really exciting because I'm really excited, like if I grow up I'll be a scientist or something.

The enhanced student outcomes were underscored by the volunteers:

It was also great seeing how the students have relaxed and gained some confidence over the course of the program ...I I believe have become more confident in completing their homework. We have had other lessons come to the surface like a dance that the boys wanted to show us and a standup comedy sketch performed by a boy that wasn't very confident at the start. Their confidence has grown with their fellow peers and homework. They've said that they come to school on a Tuesday and Thursday because they don't want to miss out on our program.

These students, based on previous school data were hard to keep engaged in their school environment but their teachers, the principal and volunteers agreed they had all been fully engaged in this program. Specifically a Principal was able to identify individuals who made enormous strides:

[He was a] very, very shy kid, but during that program, you could see his engagement level was really, really high, and he was actually experiencing success, where he's normally one of those kids who would be sitting in the background and making himself as inconspicuous as possible.

\section{Enhanced Social Capital-Transforming and Empowering}

The purpose was to use Learning Enhancement as a part of a strategy to build social capital, enhance learning, and develop powerful learning relationships. Yosso (2005) developed the concept of community cultural wealth which "focuses on and learns from the array of cultural knowledge, skills and abilities, and contacts possessed by socially marginalized groups that often go unrecognized, and unacknowledged” (Yosso, 2005: p. 69). As the principal noted effective school-community partnerships give schools a much broader range of resources and support networks on which to draw:

One of the fundamentals of the program is that at the end of the program there's a public celebration, it's very, very important, so that the children can show their parents and other siblings and their peers, as well as their other teachers, what we have achieved. So there's a public acknowledgement of it.

A student in the program agreed:

We can show our parents how to do what we do at school and how we do it and the purpose is that we can take it home and do it.

What makes this program different from the multitude of af- 
ter-school programs is that the E-LINCs project engaged disadvantaged "at-promise" youth in authentic learning. Coming from the belief that it 'takes a village to raise a child' the project provided a space where young people can learn new skills and grow their own self worth and community members can share expertise building on the collective community knowledge of the young people by improving their experiential base. By tapping into and cultivating the rich knowledge and concern of a range of community members it supports the learning of young people; and builds meaningful relationships for young people with their peers and other community members.

From the volunteers perspective they identified the strengthening of social capital in this way:

When you see their faces light up and they call your name from across the asphalt when you arrive, then they come inside and they can't wait to tell you about something that is important to them. Seeing their personalities come out and listening to them talk at the end of the session about what we achieved and what they liked about the session.

Building relationships with the boys has been rewarding and watching them participate and be enthusiastic about their learning has made the hard work worthwhile.

The principal concluded that:

The children who participated in the program were so excited to share a skill that they had .... Short term-not big gain-but if you've got a program like this running and children know that they can get into it and be involved in it, there will be growth, and importantly, they're learning a skill, and not just a skill, but they're potentially learning an interest. Because if kids learn something like that, they say, "I'm quite good at this."

By changing the social and cultural capital there was potential for the children to change their lives. The Principal clearly understands this effect:

We can't set kids on that path of thinking about what they do in a normal primary school, but you can start to develop interests that are not necessarily going to be developed in the run of the mill school day, and particularly with the backgrounds they come from in our area, that they're not that aspirational.

The schools also provided opportunities for members of the community to work in after school support and enhancement activities together with student-teacher volunteers or as leaders in their own right.

The tension between providing activities that were shaped by the children's interests and the skills of the volunteers allowed the program to be both child and adult-directed where the adult agenda was relatively modest permitting it to be responsive to the "changing needs and circumstances in the lives of low income children” (Halpern, 2002: p. 179).

Instead of just doing more of the same that has already led to the disengagement of the children, this particular outside of school program offers an excellent opportunity to provide the necessary experiences and environments to re-engage CLED children and prepare them for learning. As one of the volunteers commented,

It's not just that the children are failing to learn. They have failed to become learners.

\section{Conclusion}

Community-based after school youth development programs are well established in the USA but are new to Australia. Research in the USA indicates that these programs:
Foster the development of youth [and have] the capacity for being a force of transformation. Through developmental experiences young people learn that transformation is possiblethat they can create their own lives - and also that they can, and need to, develop their own communities. (Onore \& Gilden, 2010: p. 31)

The programs offered as part of the Enhanced Learning offered "a context for socialization, acculturation, training and problem remediation” (Onore \& Gilden, 2010: p. 31), but also the young people were afforded protection, care, opportunity for enrichment and also play. By changing the social and cultural capital there was potential for the children to change their lives.

Teacher education programs must not only transform their focus and strategy but as Noel concludes must also "work more intimately with their urban communities and community-based organisations” (Noel, 2010: p. 11). Volunteers realized this possibility:

I found it exiting to be involved in such a revolutionary idea. I liked the fact that this was something different and I wanted to be involved in that.

By doing so we move towards a more democratic and participatory form of education significantly with input from all involved. It was through "listening to and learning from community members” (Noel, 2010: p. 15) that the volunteers began to understand how they saw and understood the school and its children and their families. E-LINCs was an "extensive community-based immersion experience” (Sleeter, p. 102) and as such developed the volunteers' perspectives on CLED children as assets rather than deficits.

This research has shown that productive partnerships between schools and a university can affect inclusive teaching and learning practices, both at the school and the university level. In distinction from "homework clubs"; after-care activities; and other such activities, this intervention can have an impact on engagement levels and the learning and social outcomes of students from refugee, migrant and working class families. From a research perspective what makes this program successful was that all the participants were empowered to enhance learning outcomes as the students felt connected to and involved in their community (Zyngier, 2003). By not asking the children to do "more of the same", the students had the opportunity to experience greater community engagement leading to improved school attendance and retention, as well as better academic outcomes.

\section{References}

Anderson-Butcher, D., Stetler, E. G., \& Midle, T. (2006). A case for expanded school-community partnerships in support of positive youth development. Children \& Schools, 28, 155-163.

Anderson-Butcher, D., \& Ashton, D. (2004). Innovative models of collaboration to serve children, youths, families and communities. national association of social workers. Children \& Schools, 26, 3953.

Australian Council for Educational Research (2008). Schools first final report. Policy Analysis and Program Evaluation. http://research.acer.edu.au/policy_analysis_misc/4

Bassani, C. (2006). A test of social capital theory outside of the American context: Family and school social capital and youths' math scores in Canada, Japan, and the United States. International Journal of Educational Research, 45, 380-403. doi:10.1016/j.ijer.2007.03.001

Berg, A., Melaville, A., \& Blank, M. J. (2006). Community \& family engagement: Principals share what works. Washington: Coalition for Community Schools. 
Billett, S., \& Seddon, T. (2004). Building community through social partnerships around vocational education and training. Journal of Vocational Education and Training, 56, 51-67. doi:10.1080/13636820400200245

Bourdieu, P., \& Passeron, J.-C. (1977). Reproduction in education, society, and culture. Beverly Hills, CA: Sage.

Bullen, P., \& Onyx, J. (2005). Measuring social capital in five communities in NSW: A practitioner's guide (2nd ed.). Coogee, NSW: Management Alternatives.

Case, S., \& Hadfield, M. (2006). Community involvement in the networked learning communities program. Nottingham, UK: National College for Educational Leadership.

Centre for Multicultural Youth Issues (2003). Educational support issues for refugee \& newly arrived young people. Carlton: Centre for Multicultural Youth Issues.

Chysels, M., \& Thibodeaux, K. (2006). A New approach to business partnerships. Leadership, 36, 18-21.

Citizen Schools (2009) Our Model. URL (last checked 22 November 2010) http://www.citizenschools.org/whatwedo/ourmodel/

Clemans, A., Billett, S., \& Seddon, T. (2005). Initiating, developing and sustaining social partnerships through partnership work. In 14th National VET Research Conference. Queensland: Australian Academic Press.

Coleman, J. S. (1988). Social capital in the creation of human capital. American Journal of Sociology, 94, S95-S120. doi:10.1086/228943

Croninger, R. G., \& Lee, V. E. (2001). Social capital and dropping out of high school: Benefits to at-risk students of teachers' support and guidance. Teachers College Record, 103, 548-581.

doi:10.1111/0161-4681.00127

Curtis, D. (2007). Response to the draft technical report: Social capital and the longitudinal surveys of Australian youth. 2003 cohort. Unpublished paper for ACER.

Department of Education and Early Childhood Development (DEECD). (2008a). Beyond the school gate: A guide to school partnerships. Draft for discussion.

Department of Education and Early Childhood Development (DEECD) (2008b). Smarter Schools National Partnerships in Victoria. URL (last checked 22 November 2010)

http://www.education.vic.gov.au/about/directions/nationalpartnership s/default.htm

Dorfman, D., \& Fisher, A. (2002). Building relationships for student success: School-family-community partnerships and student achievement in the northwest. Oregon: Northwest Regional Educational Laboratory.

Dorfman, P. (2008). Newcomer students: Bridges to success. Education Canada, 48, 36-38, 40.

Finn, J. D. (1989). Withdrawing from school. Review of Educational Research, 59, 117-142.

Fredricks, J. A., Blumenfeld, P. C., \& Paris, A. H. (2004). School engagement: Potential of the concept, state of the evidence. Review of Educational Research, 74, 59-109. doi:10.3102/00346543074001059

Fullarton, S. (2002). Student engagement with school: Individual and school-level influences. Melbourne: Australian Council for Educational Research ACER.

Gale, T., \& Densmore, K. (2000). Just schooling: Explorations in the cultural politics of teaching. London: Open University Press.

Goddard, C. (2008). 20 questions about learning networks: A guide for school leaders. National college for school leadership. URL (last checked on 8 August 2008)

http://networkedlearning.ncsl.org.uk/knowledge-base/20-questions.pdf

Haberman, M. (1991). The pedagogy of poverty versus good teaching. Phi Delta Kappan, 73, 290.

Halpern, R. (2002). A different kind of child development institution: The history of after-school programs for low-income children. The Teachers College Record, 104, 178-211.

doi:10.1111/1467-9620.00160

Holloway, J. H. (2004). Research link. Educational Leadership, 61, 8990.

Hooks, B. (2003). Teaching community : A pedagogy of hope. New York: Routledge.

Howard, R. W. (2006). Bending towards justice: Service-learning and social capital as means to the tipping point. Mentoring \& Tutoring, 14, 5-15. doi:10.1080/13611260500432160
Howard, R. W. (2004). Capital gains. Principal Leadership, 5, 34-38. Israel, G. D., \& Beaulieu, L. J. (2004a). Investing in communities: Social capital's role in keeping youth in schools. Journal of the Community Development Society, 34, 35-57.

doi:10.1080/15575330409490111

Israel, G. D., \& Beaulieu, L. J. (2004b). Laying the foundations for employment: The role of social capital in educational achievement. The Review of Regional Studies, 34, 260-287.

Ladson Billings, G. (2006). It's not the culture of poverty, it's the poverty of culture: The problem with teacher education. Anthropology \& Education Quarterly, 37, 104-109. doi:10.1525/aeq.2006.37.2.104

Lane, B., \& Dorfman, D. (1997). Strengthening community networks: The basis for sustainable community renewal. URL (last checked 21 August 2008) http://www.nwrel.org/ruraled/strengthening.html

Leana, C. R., \& Pil, F. K. (2006). Social capital and organizational performance: Evidence from urban public schools. Organization Science, 17, 353-366. doi:10.1287/orsc.1060.0191

Lingard, B., Ladwig, J., Mills, M., Bahr, M., Chant, D., Warry, M., et al. (2001). Queensland School Reform Longitudinal Study: Final report, vol.1. Brisbane: Report prepared for Education Queensland by the School of Education, The University of Queensland.

Luse, P. L. (2002). Speedwriting: A teaching strategy for active student engagement. The Reading Teacher, 56, 20.

MCEETYA (1999). The adelaide declaration on national goals for schooling in the twenty-first century. Melbourne Declaration on Educational Goals for Young Australians.

MCEETYA (2008). Melbourne declaration on educational goals for young Australians.

http://www.mceecdya.edu.au/verve/_resources/National_Declaration _on_the_Educational_Goals_for_Young_Australians.pdf

McFadden, M., \& Munns, G. (2002). Student engagement and the social relations of pedagogy. British Journal of Sociology of Education, 23, 357-366. doi:10.1080/0142569022000015409

Melaville, A., Berg, A. C., \& Blank, M. J. (2006). Community-based learning: Engaging students for success and citizenship. Washington: Coalition for Community Schools.

Michael, S., Dittus, P., \& Epstein, J. (2007). Family and community involvement in schools: Results from the school health policies and programs study 2006. Journal of School Health, 77, 567-587. doi:10.1111/j.1746-1561.2007.00236.x

Michalak, J., \& Jones, S. (2008). The task of raising social capital and educational outcomes in highly disadvantaged communities in poland and england: School leadership teacher education implications. URL (last checked 24 August 2008) http://www.pef.uni-lj.si/tepe2008/papers/Jones_Michalak.pdf

Moll, L. C., Amanti, C., Neff, D., \& Gonzalez, N. (1992). Funds of knowledge for teaching: Using a qualitative approach to connect homes and classrooms. Theory Into Practice, 31, 132-141. doi:10.1080/00405849209543534

Murray, S., Mitchell, J., Gale, T., Edwards, J., \& Zyngier, D. (2004). Student disengagement from primary schooling: A review of research and practice. CASS Foundation \& Centre for Childhood Studies Faculty of Education Monash University.

Naidoo, L. (2008). Supporting African refugees in Greater Western Sydney: A critical ethnography of after-school homework tutoring centres. Educational Research for Policy and Practice, 7, 139-150. doi:10.1007/s10671-008-9046-1

Newmann, F. M. (1996). Authentic achievement: Restructuring schools for intellectual quality (1st ed.). San Francisco: Jossey-Bass Publishers.

Newmann, F., Bryk, A. S., \& Nagaoka, J. K. (2001). Authentic intellectual work and standardized tests: Conflict or coexistence? Improving Chicago's Schools (pp. 47). Chicago: Consortium on Chicago School Research.

Noel, J. (2010). Weaving teacher education into the fabric of urban schools. Teacher Education Quarterly, 37, 9-25.

Onore, C., \& Gilden, B. (2010). Preparing urban teachers as public professionals. Teacher Education Quarterly, 37, 25-44.

Pease-Alverez, L. (2000). Book review of "Subtractive schooling: U.S.Mexican youth and the politics of caring".

http://www.aaanet.org/sections/cae/aeq/br/valenzuela.htm

Plagens, G. (2003). Social capital and school performance: A locallevel test. American Political Science Association Annual Conference. 
URL (last checked 12 July 2008)

http://eric.ed.gov/ERICDocs/data/ericdocs2sql/content_storage_01/000 0019b/80/1b/77/df.pdf

Putnam, R. D. (Ed.) (2002). Democracies in flux: The evolution of social capital in contemporary society. New York: Oxford University Press.

Scales, P., Benson, P., \& Mannes, M. (2002). Grading grown-ups 2002: How do American kids and adults relate? Key Findings from a National Study.

Sleeter, C. (2001). Preparing teachers for culturally diverse schools. Journal of Teacher Education, 52, 94-106. doi:10.1177/0022487101052002002

Spoehr, J., Wilson, L., Barnett, K., Troth, T., \& Watson-Tran, A. (2007). Measuring social inclusion and exclusion in Northern Adelaide. A Report for the Department of Health. Australian Institute for Social Research.

Stewart, H. (1998). At risk or marginalised? The implications of focussing on at risk individual young people for workers with marginalised young people. YACVic Bits, 1, 4-5.

Swadener, B. B. (1995). Children and families "at promise": Deconstructing the discourse of risk. In B. B. Swadener and S. Lubeck (Eds.), Children and Families "At Promise": Deconstructing the Discourse of Risk (pp. 17-49). Albany: State University of New York Press.

Victorian Settlement Planning Committee (2005). The good practice principles guide for working with refugee young people. A Project of the Victorian Settlement Planning Committee (pp. 31). Melbourne: Department for Victorian Communities.

Yosso, T. (2005). Whose culture has capital? A critical race theory discussion of community cultural wealth. Race, Ethnicity and Educa- tion, 8, 69-91. doi:10.1080/1361332052000341006

Zyngier, D. (2003). Connectedness-isn't it time that education came out from behind the classroom door and rediscovered Social Justice. Social Alternatives, 22, 41-49.

Zyngier, D. (2004). Engaging pedagogies and pedagogues-What does student engagement look like in action? Proceedings of the AARE 2004 International Education Research Conference: Doing the Public Good: Positioning Education Research, Melbourne, Australia.

Zyngier, D. (2007a). The challenge of student engagement-What the students say they want-putting young people at the centre of the conversation. Learning Landscapes, 1.

Zyngier, D. (2007b). Listening to teachers-listening to students substantive conversations about resistance, empowerment and engagement. Teachers and Teaching Theory and Practice Journal, 13, 327347.

Zyngier, D. (2008). Conceptualising student engagement: Doing education not doing time. Teaching and Teacher Education, 24, 1765-1776. doi:10.1016/j.tate.2007.09.004

Zyngier, D. (2009a). Doing it to (for) boys (again): Do we really need more books telling us there is a problem with boys' underachievement in education? Gender and Education, 21, 111-118. doi:10.1080/09540250802580844

Zyngier, D. (2011). Conceptualising risk: Left numb and unengaged and lost in a no-man's-land or what (seems to) work for at-risk students. International Journal of Inclusive Education, 15, 195-210.

Zyngier, D., \& Gale, T. (2003). Engaging programs: How are Australian schools responding to low student retention? Paper presented at the AARE Annual Conference: Education Risks, Research \& Dilemmas, Auckland New Zealand. 